\title{
Peningkatan Hasil Belajar Rangka dan Fungsinya Melalui Model Problem Based Learning (PBL)
}

\author{
Sri Lindayani
}

SDN Tanggung 1 Kota Blitar

Email : srilindayani@yahoo.com

\section{Tersedia Online di \\ http://www.jurnal.unublitar.ac.id/ index.php/briliant}

\begin{tabular}{l}
\hline Sejarah Artikel \\
\hline Diterima pada 3 April 2017 \\
Disetuji pada 8 April 2017 \\
Dipublikasikan pada 1 Mei 2017 \\
Hal. 214-224
\end{tabular}

Kata Kunci:

rangka, problem based learning

\begin{abstract}
Penelitian ini bertujuan untuk menguji aplikasi, meningkatkan hasil belajar, dan perbedaan hasil belajar pada kerangka manusia melalui Pembelajaran Berbasis Masalah (PBL). Penelitian ini menggunakan model dari Kemmis dan Taggart. yaitu model siklus yang terdiri dari empat langkah: perencanaan, tindakan, observasi dan refleksi. Hasil penelitian menunjukkan Problem Based Learning (PBL) dapat meningkatkan hasil belajar kerangka manusia di kelas IV.
\end{abstract}

Mengajar dalam prakteknya merupakan suatu proses penciptaan lingkungan, baik dilakukan guru maupun siswa agar terjadi meliputi juga penataan nilai-nilai dan kepercayaan yang akan diupayakan untuk dicapai (Joice\& Weil, 1980;1). Demikian juga dalam mengajar IPA. Salah satu tujuan mata pelajaran IPA di SD adalah mengembangkan keterampilan proses untuk menyelidiki alam sekitar, memecahkan masalah dan membuat keputusan. Keterampilan proses yang digunakan dalam pembelajaran IPA didasarkan serangkaian langkah-langkah kegiatan yang biasanya ditempuh oleh para ilmuan untuk mendapatkan atau menguji suatu pengetahuan yang dapat berupa konsep atau prinsip. Perlu kita ingat bahwa IPA dimulai dengan mengajukan suatu pertanyaan. Kemudian dilanjutkan dengan proses penyelidikan. Hal ini juga terjabarkan dalam Standar Kompetensi nomor 1 yaitu Memahami hubungan antara struktur organ tubuh manusia dengan fungsinya serta pemeliharaannya, dengan Kompetensi Dasar nomor 1.1 yaitu mendeskripsikan hubungan antara struktur rangka tubuh manusia dengan fungsinya serta pemeliharaannya.

Berdasarkan pengamatan peneliti didalam proses pembelajaran IPA di kelas IV SDN Tanggung 1 Kota Blitar diperoleh permasalahan sebagai berikut: 1) Hasil belajar siswa dalam Mendeskripsikan hubungan antara struktur rangka tubuh manusia dengan fungsinya masih rendah. Terbukti hanya ada 4 siswa $(12,9 \%)$ yang tuntas dan 27 siswa (87\%) tidak tuntas dari 31 jumlah siswa SDN Tanggung 1 kelas IV. KKM untuk mata pelajaran IPA yang ditetapkan di SDN Tanggung 1 adalah 75 dengan ketuntasan klasikal 85\%. 2) Kurangnya motivasi siswa dalam belajar karena kegiatan belajar mengajar di sekolah berlangsung secara formal dan metode yang digunakan kurang bervariasi yaitu metode ceramah dan tanya jawab. 3) Siswa banyak yang pasif dan tidak dapat menyelesaikan tugas tepat waktu sehingga dapat menghambat proses pembelajaran. 
Paparan di atas memberikan informasi bahwa hasil belajar siswa masih rendah. Hal tersebut disebabkan oleh perilaku siswa yang tidak siap menerima pelajaran serta proses pembelajaran yang kurang melibatkan siswa sehingga tujuan pembelajaran yang dirancang guru tidak tercapai. Oleh karena itu guru perlu melakukan perbaikan pembelajaran agar dapat meningkatkan hasil belajar siswa. Dalam melakukan perbaikan pembelajaran banyak cara yang dilakukan seperti memilih media yang cocok, memilih metode yang sesuai, ataupun model pembelajaran yang dipandang sesuai untuk membangkitkan aktivitas siswa dan hasil belajarnya.

Untuk mengatasi masalah di atas peneliti berupaya menggunakan salah satu model pembelajaran yang sesuai dengan materi dan karakteristik pembelajaran IPA, yaitu Model Pembelajaran Berbasis Masalah (Problem Based Learning)

Problem Based Learning (PBL) merupakan suatu pendekatan pembelajaran atau metode mengajar yang fokusnya pada siswa dengan mengarahkan siswa menjadi pembelajar mandiri yang terlibat langsung secara aktif tdalam pembelajaran berkelompok. PBL membantu siswa untuk mengembangkan keterampilan mereka dalam memberikan alasan dan berpikir ketika mereka mencari data atau informasi agar mendapatkan solusi untuk suatu masalah yang otentik

Pembelajaran berbasis masalah merupakan suatu model pembelajaran yang menantang peserta didik untuk "belajar bagaimana belajar", bekerja secara berkelompok untuk mencari solusi dari permasalahan dunia nyata.

Menurut Kamdi (2007:77) Model Problem Based Learning diartikan sebagai model pembelajaran yang di dalamnya melibatkan siswa untuk berusaha memecahkan masalah melalui beberapa tahap metode ilmiah sehingga siswa diharapkan mampu mempelajari pengetahuan yang berkaitan dengan masalah tersebut dan sekaligus siswa diharapkan akan memiliki pengetahuan yang berkaitan dengan masalah tersebut dan sekaligus siswa diharapkan akan memiliki keterampilan dalam memecahkan masalah.

Nurhadi (2004 : 109) menjelaskan bahwa model pembelajaran Problem Based Learning adalah model pembelajaran yang menggunakan masalah dunia nyata sebagai suatu konteks untuk belajar tentang cara berpikir kritis dan keterampilan pemecahan masalah, serta untuk memperoleh pengetahuan dan konsep yang esensial dari materi pelajaran. Menurut Tatang Herman (2006 : 4) Problem Based Learning memiliki fokus utama yaitu memposisikan guru sebagai perancang dan organisator pembelajaran. Guru membimbing dan mengarahkan siswa untuk mengeksplorasi pengetahuan dan kemampuan yang dimilikinya untuk menyelesaikan masalah yang diberikan.

PBL menjadi sebuah pendekatan pembelajaran yang berusaha menerapkan masalah yang terjadi di dunia nyata sebagai sebuah konteks bagi para siswa dalam berlatih bagaimana cara berpikir kritis dan mendapatkan keterampilan dalam pemecahan masalah, serta tak terlupakan untuk mendapatkan pengetahuan sekaligus konsep penting dari materi ajar yang dibicarakan.

Dasar pemikiran inilah yang penulis anggap dapat memberikan bantuan kepada siswa untuk dapat meningkatkan hasil belajarnya. Dengan demikian penelitian ini sangat penting dan mendesak untuk segera dilakukan. 


\section{METODE}

Metode yang digunakan pada penelitian ini adalah Penelitian Tindakan Kelas. Wardhani (2011) mengisyaratkan karakteristik PTK sebagai berikut: 1) An inquiry of practice from within (penelitian berawal dari kerisauan guru akan kinerjanya). 2) Self-reflective inquiry (metode utama adalah refleksi diri, bersikap agak longgar, tetapi tetap mengikuti kaidah-kaidah penelitian). 3) Fokus penelitian berupa kegiatan pembelajaran. 4) Tujuan memperbaiki pembelajaran.

Metodologi penelitian ini yang dipakai adalah penelitian kualitatif. Menurut Denzin dan Lincoln (1994) dalam Wardhani (2011) penelitian kualitatif merupakan suatu proses dari langkah-langkah yang melibatkan peneliti, paradigma teoritis, dan interpretative, strategi penelitian, metode pengumpulan data dan analisis data empiris, maupun pengembangan intrepretasi dan pemaparan. Untuk itu peneliti merencanakan teknik-teknik kualitatif seperti observasi, pengukuran, dokumen dan catatan lapangan.

Materi pelajaran yang diteliti adalah mendeskripsikan hubungan antara struktur rangka manusia dengan fungsinya. Penelitian ini bertempat di SD Negeri Tanggung 1 Kota Blitar. Subyek penelitian adalah siswa kelas IV SDN Tanggung 1 Kota Blitar yang berjumlah 31 siswa yang terdiri dari 17 laki-laki dan 14 perempuan. Kelas ini dipilih oleh peneliti karena kelas tersebut merupakan tanggung jawab peneliti sebagai guru kelas tersebut.

Teknik pengumpulan data yang digunakan dalam penelitian ini meliputi observasi, dokumentasi dan tes. Teknik observasi digunakan untuk mengamati gejala-gejala yang tampak dalam proses pembelajaran yang meliputi kerjasama dan keaktifan. Keaktifan yang kami maksudkan di sini adalah kemauan dan kemampuan siswa dalam memberikan tanggapan dalam diskusi kelas (presentasi). Tanggapan bisa berupa pertanyaan, saran, kritikan ataupun himbauan mengenai masalah yang sedang dibicarakan. Teknik observasi juga dilakukan oleh pengamat kepada peneliti selama proses pembelajaran. Dokumentasi yang dimaksud dalam penelitian ini mencakup dokumentasi foto dan dokumen portofolio siswa. Tes digunakan untuk mengumpulkan data tentang kemampuan siswa mengerjakan soal-soal tes dalam mendeskripsikan hubungan antara struktur rangka manusia dengan fungsinya. Teknik tes dilakukan pada setiap akhir pertemuan kegiatan pembelajaran dengan menggunakan Lembar Evaluasi/Lembar Kerja Individu.

Instrumen Penelitian yang digunakan dalam penelitian ini terdiri dari: Silabus, RPP, Kisi-kisi Soal Evaluasi, Lembar Evaluasi Siswa, Lembar Observasi, Lembar Pengamatan Proses Kerja Kelompok, Lembar APKG oleh pengamat, Lembar Observasi aktivitas guru dan siswa, Lembar Observasi Pengelolaan Pembelajaran, Angket Siswa, Catatan Lapangan.

Untuk mengetahui keefektifan suatu metode dalam kegiatan pembelajaran perlu diadakan analisis data. Data-data yang diperoleh berupa hasil belajar secara kelompok dan individu yang diperoleh dari instrumen penelitian dipaparkan kemudian dianalisis untuk mengetahui sejauh mana efektivitas metode pembelajaran yang digunakan terhadap siswa. Hal tersebut juga dimaksudkan sejauh mana pembelajaran menggunakan metode pembelajaran Problem Based Learning dapat meningkatkan hasil belajar siswa baik secara kelompok maupun individu.

Pada penelitian ini data yang telah terkumpul dianalisis secara deskriptif, baik deskriptif kualitatif maupun deskriptif kuantitatif. Data kualitatif berupa

216 BRILIANT: Jurnal Riset dan Konseptual

Volume 2 Nomor 2, Mei 2017 
catatan pengamatan, dokumen portofolio siswa dan dokumen foto. Data yang dianalisis secara deskriptif kuantitatif adalah data tentang kemampuan mendeskripsikan hubungan struktur rangka manusia dengan fungsinya yang dinyatakan dengan nilai (score) yang dicapai siswa dari hasil tes. Analisis ini dihitung dengan menggunakan statistik sederhana yaitu : a) Menilai evaluasi dengan melakukan penjumlahan skor yang diperoleh siswa, yang selanjutnya dikali 10 sehingga diperoleh nilai maksimal 100. b) Menentukan ketuntasan individu dan klasikal. Siswa yang tuntas adalah siswa yang mendapat nilai lebih dari atau samadengan 75. Sementara itu siswa yang tidak tuntas adalah siswa yang mendapat nilai kurang dari 75. Ketuntasan klasikal diperoleh jika 85\% siswa telah mendapat ketuntasan individu.

Keberhasilan Kegiatan Kelompok dikatakan berhasil jika setiap siswa aktif bekerja sama dalam kelompok dan aktif memberikan tanggapan pada saat diskusi kelas. Kebershasilannya juga dapat diketahui melalui peningkatan rata-rata Nilai Akhir setiap akhir siklus.

\section{HASIL}

Penelitian tindakan kelas ini dilaksanakan dalam 2 siklus, dalam setiap siklus dilaksanakan 2 kali pertemuan. Pada setiap akhir pertemuan, guru yang juga bertindak sebagai peneliti memberikan evaluasi kepada siswa. Dalam pelaksanaannya peneliti bekerjasama dengan guru senior sebagai pengamat.

\section{Siklus I Pertemuan I}

Rencana pembelajaran yang telah disusun dengan model PBL kemudian dilaksanakan dalam tindakan. Tindakan siklus I pertemuan I diawali dengan salam pembuka, mengecek kehadiran siswa, mengkondisikan siswa untuk siap melaksanakan pembelajaran model PBL. Kegiatan inti pada tindakan siklus I pertemuan I yaitu : Pada Fase 1 siswa sudah terbagi menjadi 8 kelompok yang masing-masing terdiri dari 3-4 siswa yang heterogen. Guru menyampaikan tujuan pembelajaran, membagikan peralatan dan bahan yang diperlukan, seperti lem, gunting dan spidol. Pada Fase 2 masing-masing kelompok mendapatkan Lembar Kerja Kelompok. Pembagian LKK dilakukan dengan memanggil perwakilan dari tiap kelompok untuk mengambil 1 lembar yang memuat langkah-langkah yang akan ditempuh dalam pembelajaran PBL, 1 lembar kertas buffalo untuk menempelkan hasil kerja kelompok. Setiap kelompok melakukan kegiatan sesuai dengan petunjuk-petunjuk yang terdapat dalam LKK. Siswa mempresentasikan hasil kerja kelompoknya di depan kelas dimana guru bertindak sebagai moderator. Setiap kelompok mendapat kesempatan untuk mempresentasikan hasil kerja kelompoknya sementara itu kelompok lain menanggapinya. Di akhir tindakan siklus I pertemuan I, siswa mendapat lembar evaluasi yang berisi 10 soal untuk mengetahui peningkatan hasil belajar siswa dalam mengelompokkan bagianbagian rangka manusia dan mengidentifikasi nama-nama unsur pembentuk rangka manusia.

Berdasarkan pengamatan selama pembelajaran dapat dilihat bahwa tindakan yang dilakukan guru sudah mengacu pada rencana pembelajaran yang telah dipersiapkan. Namun dari hasil analisis evaluasi siswa diketahui bahwa hasil belajar siswa secara klasikal belum tuntas, sebagaimana dapat kita lihat pada tabel berikut ini:

217 BRILIANT: Jurnal Riset dan Konseptual Volume 2 Nomor 2, Mei 2017 
Tabel 1 Rekapitulasi Analisis Hasil Evaluasi Pada Siklus I Pertemuan I

\begin{tabular}{llll}
\hline No. & Uraian & Jumlah & Dalam \\
\hline 1 & $\begin{array}{l}\text { Siswa yang tuntas belajar } \\
\text { (Ketuntasan Klasikal) }\end{array}$ & 13 & $41,93 \%$ \\
2 & Siswa yang tidak tuntas belajar & 18 & $58,07 \%$
\end{tabular}

Tabel diatas memberi gambaran bahwa hanya 13 anak yang nilainya $\geq$ KKM dan 18 anak kurang dari KKM. Sedangkan dalam proses kegiatan kelompok khususnya saat diskusi hanya terdapat 14 anak yang memberi tanggapan sebagaimana terlihat dalam tabel berikut ini :

Tabel 2 Rekapitulasi Hasil Pengamatan Proses Kerja Kelompok

\begin{tabular}{lll}
\hline No. & Uraian & Jumlah \\
\hline 1 & Jumlah anak yang aktif menanggapi ketika & 14 anak \\
2 & Rata-Rata Proses Kerja Kelompok & 44,65 \\
\hline
\end{tabular}

Berdasarkan rekapitulasi di atas maka peneliti melakukan refleksi tentang segala sesuatu yang sudah terlaksana maupun yang belum terlaksana agar kesalahan yang sama tidak terulang pada pembelajaran berikutnya. Hal-hal yang memerlukan perbaikan antara lain : Guru (peneliti) kurang cermat dalam mempersiapkan alat-alat. Guru hanya menyiapkan 1 gunting untuk 1 kelompok, sementara tugas setiap kelompok tidak sama. Ada yang harus menggunting tiga kotak nama-nama tulang penyusun rangka (seperti kelompok D dan E), ada yang 6 kotak ada juga yang harus menggunting sampai 16 bagian (kelompok $\mathrm{H}$ ) sehingga ada beberapa kelompok yang tidak dapat menyelesaikan tugasnya tepat waktu. Namun untuk mengatasi masalah dalam keterbatasan waktu, akhirnya kelompok yang sudah selesai terlebih dahulu diberi kesempatan untuk presentasi terlebih dahulu, tanpa menunggu hingga semua kelompok dapat menyelesaikan tugas kelompoknya. Dalam hal keaktifan saat diskusi, siswa tampak masih enggan memberi tanggapan. Hal tersebut disebabkan oleh beberapa faktor yaitu : 1)

Belum selesai mengerjakan tugas kelompok. 2) Belum terbiasa berdiskusi dan memberikan tanggapan

Pada pertemuan berikutnya peneliti berupaya untuk menyesuaikan dengan jumlah kelompoknya yaitu menjadi enam kelompok, sehingga formasi kelompok perlu diubah. Jika satu kelas terdiri dari 31 siswa maka jika dibagi enam masing-masing kelompok beranggotakan 5-6 siswa.

Untuk mengatasi masalah peralatan yang kurang lengkap, maka sehari sebelum pelaksanaan guru meminta siswa untuk membawa peralatan yang diperlukan untuk keesokan harinya. Sedangkan untuk mengatasi siswa yang kurang aktif dalam kegiatan diskusi maka guru berupaya memotivasi siswa selama kegiatan diskusi berlangsung.

218 BRILIANT: Jurnal Riset dan Konseptual Volume 2 Nomor 2, Mei 2017 


\section{Siklus I Pertemuan II}

Sesuai dengan rancangan yang sudah diperbaiki maka peneliti mengubah formasi kelompok menjadi 6 kelompok, dengan masing-masing kelompok terdiri dari 5-6 siswa. Sama halnya dengan tahap perencanaan pada siklus I pertemuan I, peneliti juga mempersiapkan RPP, membuat lembar kerja kelompok (LKK), menyusun lembar evaluasi yang berisi soal-soal yang akan digunakan untuk mengukur kemampuan siswa dalam mendeskripsikan bentuk dan jenis rangka manusia.

Pelaksanaan pembelajaran berjalan sesuai dengan langkah-langkah yang terdapat dalam RPP. Pada akhir evaluasi siswa mengerjakan lembar kerja individu/lembar evaluasi yang berisi 10 soal berbentuk isian.

Tabel 3 Rekapitulasi Analisis Hasil Evaluasi Pada Siklus I Pertemuan II

\begin{tabular}{llll}
\hline No. & Uraian & Jumlah & Dalam \\
\hline 1 & $\begin{array}{l}\text { Siswa yang tuntas belajar } \\
\text { (Ketuntasan Klasikal) }\end{array}$ & 17 & $54,84 \%$ \\
2 & Siswa yang tidak tuntas belajar & 14 & $45,16 \%$
\end{tabular}

Tabel 4 Rekapitulasi Hasil Pengamatan Proses Kerja Kelompok

\begin{tabular}{lll}
\hline o. & Uraian & Jumla \\
\hline $\begin{array}{c}\text { Jumlah anak yang aktif menanggapi } \\
\text { ketika diskusi } \\
\text { Rata-Rata Proses Kerja Kelompok }\end{array}$ & 16 \\
& 48,44 \\
\hline
\end{tabular}

Berdasarkan tabel di atas dapat diketahui bahwa terdapat peningkatan ketuntasan belajar siswa sebesar $12,91 \%$. Hal ini cukup menggembirakan namun belum mencapai target ketuntasan klasikal yaitu 85\%, sehingga perlu dilanjutkan dengan siklus kedua. Keaktifan siswa dalam kegiatan kelompok hanya bertambah dua anak yang memberikan tanggapan menjadi 16 anak dengan rata-rata proses kerja kelompok meningkat menjadi 48,44. Ketuntasan klasikal dalam siklus I dengan dua pertemuan jika dirata-rata sebesar $48,385 \%$

Melalui pengamatan secara langsung dapat diketahui terdapat kesalahpahaman pada siswa yaitu ketika memasuki fase ketiga dimana guru memantau siswa dengan berkeliling mengunjungi setiap kelompok, peneliti menemukan bahwa ada ketidaksesuaian antara hasil kerja kelompok dengan masalah yang diberikan di LKK. Pada masalah nomor terakhir setiap LKK setiap kelompok ditugaskan untuk mewarnai bagian yang menunjukkan bentuk atau jenis tulang tertentu menggunakan spidol warna. Namun yang terjadi adalah bahwa semua bagian gambar rangka manusia diberi warna dengan warna yang berbeda. Untuk mengatasi hal tersebut guru sebagai peneliti segera mengambil tindakan dengan menginformasikan kepada siswa untuk memberi keterangan di bagian lembar kerja yang kosong terkait dengan warna. Contoh : Warna merah

219 BRILIANT: Jurnal Riset dan Konseptual Volume 2 Nomor 2, Mei 2017 
untuk tulang pipa, warna kuning untuk tulang pipih dsb. Untuk lebih jelasnya dapat dilihat pada lampiran dokumentasi foto no. 21

Hal tersebut disebabkan oleh beberapa hal yaitu : 1) Siswa kurang cermat membaca permasalahan yang terdapat dalam LKK 2) Informasi yang diberikan guru kurang didengar siswa karena terlalu asyik dengan kegiatan mewarnai.

Nilai siswa pada siklus pertama pertemuan kedua ini belum mencapai ketuntasan klasikal. Hal tersebut disebabkan oleh : 1) Pada fase kelima kurang maksimal 2) Alat peraga yang digunakan berupa poster gambar rangka manusia terlalu kecil, sehingga siswa yang duduk di deretan belakang tidak dapat melihat dengan jelas.

Berdasarkan data-data tersebut di atas peneliti berencana memperbaiki kekurangan yang telah terjadi dengan berbagai cara antara lain : Memotivasi siswa untuk mau membaca terlebih dahulu setiap permasalahan yang diberikan pada tahap dalam LKK maupun kegiatan individu, membimbing siswa untuk selalu cermat dalam menyelesaikan masalah, menambah media pembelajaran dengan menggunakan Proyektor.

\section{Siklus II Pertemuan I}

Pada tahap ini peneliti membagi siswa kembali menjadi 8 kelompok. Setiap kelompok akan menyelesaikan permasalahan yang berbeda dari kelompok yang lain. Pelaksanaan pembelajaran berjalan sesuai dengan langkah-langkah yang terdapat dalam RPP. Pada akhir evaluasi siswa mengerjakan lembar kerja individu/lembar evaluasi yang berisi 10 soal berbentuk isian.

Pada tahap ini dengan bimbingan guru, anak-anak sudah mulai aktif membaca dahulu setiap permasalahan yang ada dalam LKK. Dengan demikian sudah tidak terjadi lagi kesalahpahaman dalam pengerjaan LKK. Anak-anak juga dapat memperagakan gerakan-gerakan yang melibatkan persendian tertentu.

\section{Tabel 5 Rekapitulasi Analisis Hasil Evaluasi Pada Siklus II Pertemuan I}

\begin{tabular}{llll}
\hline No. & Uraian & Jumlah & Dalam \\
\hline 1 & $\begin{array}{l}\text { Siswa yang tuntas belajar } \\
\text { (Ketuntasan Klasikal) }\end{array}$ & 21 & $67,74 \%$ \\
2 & Siswa yang tidak tuntas belajar & 10 & $32,26 \%$ \\
\hline
\end{tabular}

Berdasarkan tabel di atas dapat diketahui bahwa terdapat peningkatan ketuntasan belajar siswa sebesar $12,90 \%$. Peningkatan tersebut tentu menurun jika dibandingkan peningkatan pada pertemuan sebelumnya yaitu sebesar $12,91 \%$. Penurunannya sebesar $0,01 \%$. Tetapi jika ditinjau dari segi ketuntasan sudah dapat dikatakan mendekati ketuntasan klasikal $85 \%$. 


\section{Tabel 6 Rekapitulasi Hasil Pengamatan Proses Kerja Kelompok}

\begin{tabular}{lll}
\hline No. & Uraian & Jumlah \\
\hline 1 & Jumlah anak yang aktif menanggapi ketika & 23 anak \\
2 & Rata-Rata Proses Kerja Kelompok & 58,95 \\
\hline
\end{tabular}

Pada Siklus kedua pertemuan pertama ini, peneliti menemukan fakta bahwa siswa yang benar-benar aktif memberikan tanggapan telah bertambah menjadi 23 anak dengan rata-rata proses kerja kelompok menjadi 58,95

Ketuntasan klasikal yang belum tercapai kemungkinan disebabkan oleh beberapa hal yaitu : permasalahan yang diterima oleh setiap kelompok berbeda, sehingga setiap siswa kurang memahami materi yang disajikan oleh kelompok lain, suara siswa yang sedang menyajikan hasil kelompok pada presentasi kurang dapat didengar oleh kelompok lain yang berada di belakang.

Untuk lebih meningkatkan hasil belajar siswa maka peneliti mengubah bentuk permasalahan pada Lembar Kerja Kelompok. Pada pertemuan sebelumnya permasalahan dalam LKK selalu berbeda setiap kelompok yang mengakibatkan pemahaman siswa hanya sepotong-sepotong.

\section{Siklus II Pertemuan II}

Pelaksanaan pembelajaran berjalan sesuai dengan langkah-langkah yang terdapat dalam RPP. Pada akhir evaluasi siswa mengerjakan lembar kerja individu/lembar evaluasi yang berisi 10 soal berbentuk isian.

Pada pertemuan keempat ini anak-anak sudah terbiasa dengan kegiatan menggunakan model pembelajaran PBL, sehingga proses kerja kelompok berjalan lancar.

Hasil analisis evaluasi dapat kita lihat dalam tabel berikut ini :

Tabel 7 Rekapitulasi Analisis Hasil Evaluasi Pada Siklus I Pertemuan II

\begin{tabular}{llll}
\hline No. & Uraian & Jumlah & Dalam \\
\hline 1 & $\begin{array}{l}\text { Siswa yang tuntas belajar } \\
\text { (Ketuntasan Klasikal) }\end{array}$ & 27 & $87 \%$ \\
2 & Siswa yang tidak tuntas belajar & 4 & $13 \%$ \\
\hline
\end{tabular}




\section{Tabel 8 Rekapitulasi Hasil Pengamatan Proses Kerja Kelompok}

\begin{tabular}{lll}
\hline No. & Uraian & Jumlah \\
\hline 1 & Jumlah anak yang aktif menanggapi ketika & 28 anak \\
2 & Rata-Rata Proses Kerja Kelompok & 65,24 \\
& & \\
\hline
\end{tabular}

Berdasarkan tabel 4.7 dapat diketahui bahwa siswa yang tuntas telah bertambah menjadi 27 anak dengan ketuntasan klasikal menjadi $87 \%$. Berarti terdapat peningkatan sebesar $19,26 \%$ jika dibandingkan dengan pertemuan sebelumnya. Ketuntasan Klasikal rata-rata pada pada siklus kedua sebesar $77,37 \%$.

Tabel 4.8 menunjukkan bahwa siswa kelas IV SDN Tanggung 1 semakin antusias dengan pembelajaran IPA khususnya model PBL, terbukti dengan semakin banyak siswa yang mau berpartisipasi dalam kegiatan diskusi kelas/presentasi. Pada pertemuan keempat ini telah ada 28 siswa yang menanggapi kelompok lain yang sedang presentasi.

\section{PEMBAHASAN}

Penelitian ini dilakukan di SDN Tanggung 1 tepatnya kelas IV pada mata pelajaran IPA bersamaan dengan kegiatan belajar mengajar. Berdasarkan data yang diperoleh dan deskripsi temuan dapat diketahui model pembelajaran yang bervariasi dan menyenangkan akan membangun minat belajar siswa

Keberhasilan suatu pembelajaran tidak lepas dari kreativitas seorang guru, sebagai pengembang kurikulum, jika perannya ini tidak dijalankan dengan baik dapat mengakibatkan pembelajaran tidak berhasil.

Sumiati dan Asra (2011:139) menegaskan "Guru dalam proses pembelajaran hendaknya mengkondisikan siswa agar dapat mengembangkan kemampuannya dengan optimal. Siswa itu sendirilah yang aktif dengan daya dan karyanya sehingga mempunyai prakarsa dan inisiatif sendiri untuk mengamati, menginterpretasi, menilai, memecahkan, dan mengkomuni-kasikan berbagai masalah yang dihadapi."

Dengan penerapan model pembelajaran PBL siswa mendapatkan pengetahuan dan pengalaman baru dalam memahami dan menyelesaikan berkaitan dengan rangka manusia dan fungsinya. Dengan penerapan PBL akan merangsang memecahkan masalah sesuai dengan kemampuannya. Hal ini sejalan dengan pemikiran Sumiati dan Asra (2009: 139) bahwa siswa hendaknya dirangsang dan didorong mengenal, merumuskan dan memecahkan masalah sesuai dengan kemampuannya. Pada setiap akhir pertemuan guru menginformasikan kepada siswa agar mempelajari materi selanjutnya, sehingga pembelajaran berikutnya bisa berjalan lancar. Adapun aktivitas guru yang paling dominan pada siklus II yaitu dengan menambah media peraga proyektor untuk memperjelas fase ke lima (analisis dan evaluasi proses pemecahan masalah). Penambahan media tersebut bertujuan agar siswa dapat menyimak penguatan yang diberikan oleh guru. Pada siklus kedua guru juga mengubah bentuk permasalahan dalam LKK menjadi satu permasalahan dengan banyak jawaban. Hal tersebut dilakukan untuk meningkatkan pemahaman siswa secara keseluruhan

222 BRILIANT: Jurnal Riset dan Konseptual Volume 2 Nomor 2, Mei 2017 
agar hasil belajar siswa lebih meningkat. Pada proses presentasi dan diskusi kelas, guru memberikan motivasi agar siswa lebih aktif memberi tanggapan.

Penerapan model pembelajaran Problem Based Learning dapat meningkatkan hasil belajar siswa tentang rangka manusia dan fungsinya, dengan ketuntasan belajar pada pertemuan kedua siklus kedua mencapai $87 \%$ atau 27 siswa dari 31 siswa sudah tuntas belajar. Kenaikan rata-rata hasil belajar siswa Siklus I dan Siklus II yaitu sebesar 28,985\%

\section{KESIMPULAN}

Dari hasil kegiatan pembelajaran yang telah dilakukan sebanyak dua siklus dengan masing-masing siklus terdiri dari dua pertemuan dan berdasarkan seluruh pembahasan serta analisis yang telah dilakukan maka dapat diambil simpulan sebagai berikut: Dengan menerapkan model pembelajaran Problem Based Learning (PBL) dapat meningkatkan hasil belajar siswa yang ditunjukan dengan ketuntasan belajar klasikal yang terus meningkat.

Peningkatan hasil belajar siswa dengan menerapkan model pembelajaran PBL setiap pertemuan adalah sebagai berikut : dari Siklus I pertemuan I ke pertemuan II meningkat $12,91 \%$ b) dari Siklus I pertemuan II ke Siklus II pertemuan I meningkat sebesar 12,90\% kemudian meningkat sebesar 19,26\% pada pertemuan II siklus II. Peningkatan hasil belajar siswa dari siklus I ke siklus II rata-rata sebesar $28,985 \%$.

\section{SARAN}

Dari hasil penelitian serta perolehan data dari uraian sebelumnya, agar proses belajar mengajar IPA lebih efektif dan lebih memberikan hasil yang optimal bagi siswa, maka sebagai guru perlu memperhatikan beberapa hal yaitu melaksanakan model PBL memerlukan persiapan yang cukup matang, sehingga guru harus mampu menentukan atau memilih topik yang benar-benar bisa diterapkan dengan model PBL. Guru hendaknya lebih sering melakukan pembelajaran dengan berbagai metode dan model pembelajaran, supaya siswa dapat menemukan pengetahuan baru, memperoleh konsep dan keterampilan, sehingga siswa mampu memecahkan masalah-masalah yang dihadapinya dalam kehidupan sehari-hari.

\section{DAFTAR RUJUKAN}

Djamarah, Syaiful Bahri. 2006. Guru dan Anak dalam Interaksi Edukatif : Suatu Pendekatan Teoritis Psikologis. Jakarta: PT. Rineka Cipta

Haryanto. 2007. Sains Untuk Sekolah Dasar IV. Jakarta: Erlangga

Hastuti, Retno. 2011. Panduan pendidik Ilmu Pengetahuan Alam. Klaten: PT Intan Pariwara.

Hollingsworth, Pat., \& Lewis, Gina. 2008. Pembelajaran Aktif. Jakarta: PT. Indeks

Kamdi, W dkk. 2007. Model-Model Pembelajaran Inovatif. Malang: Universitas Negeri Malang.

Kemmis, S., \& Mc Taggart, R. 2002. The Action Research Plane. Victoria: Deakin University.

Nasution, S. 1983. Sosiologi Pendidikan. Bandung: Jemmars. 
Pusat Pengembangan Profesi Pendidik Badan Pengembangan Sumber Daya Manusia Pendidikan dan Kebudayaan dan Penjaminan Mutu Pendidikan. 2014. Materi Pelatihan Guru Implementasi Kurikulum 2013 Tahun 2014. Disajikan Dalam Workshop Impelentasi Kurikulum 2013, Dinas Pendidikan Daerah Kota Blitar, 26-30 Juni 2014.

Poerwadarminta, WJS. 1987. Kamus Umum Bahasa Indonesia. Pusat Pembinaan dan Pengembangan Bahasa. Jakarta: Departemen Pendidikan dan Kebudayaan.

Rahardjo, Dwi Ilham. 2012. Model-Model Pembelajaran Cooperative Learning. Makalah disajikan dalam Workshop Pengembangan Karier Guru dan Penelitian Tindakan Kelas KKG Gugus 09 Kota Blitar Juni 2012

Rositawaty, S. 2008. Senang Belajar Ilmu Pengetahuan Alam 4.Jakarta:Pusat Perbukuan, Departemen Pendidikan Nasional.

Sudjana, Nana. 1989. Penilaian Hasil Proses Belajar Mengajar. Bandung: PT. Remaja Rosdakarya.

Sumiati \& Asra. 2009. Metode Pembelajaran. Bandung: CV Wacana Prima.

Sutarno, Nono. 2004. Materi dan Pembelajaran IPA SD. Jakarta: Pusat Penerbitan Universitas Terbuka

Trianto. 2012. Model PembelajaranTerpadu, Konsep, Strategi, dan Implementasi dalam Kurikulum Tingkat Satuan Pendidikan (KTSP) Jakarta: PT Bumi Aksara

Wardhani, IGK. 2011. Penelitian Tindakan Kelas. Jakarta: Universitas Terbuka. 